\title{
religion

\section{God's World Is Not an Animal Farm - Or Is It? The Catachrestic Translation of Gender Equality in African Pentecostalism}

\author{
AdriaAn S. van KLINKEn*
}

\begin{abstract}
Building on scholarly debates on Pentecostalism, gender and modernity in Africa, this article engages a postcolonial perspective to explore and discuss the ambivalent, even paradoxical nature of African Pentecostal gender discourse. It analyses the conceptualization of gender equality, in particular the attempt to reconcile the notions of 'male-female equality' and 'male headship', in a sermon series delivered by a prominent Zambian Pentecostal pastor, and argues that the appropriation and interruption of Western notions of gender equality in these sermons can be interpreted, in the words of Homi Bhabha, as a catachrestic postcolonial translation of modernity. Hence, the article critically discusses the Western ethnocentrism in some scholarly debates on gender and Pentecostalism in Africa, and points to some of the fundamental questions that Pentecostalism and its ambivalent gender discourse pose to gender-critical scholarship in the study of religion.
\end{abstract}

\section{Keywords}

Pentecostalism; gender equality; gender paradox; postcoloniality; modernity; Africa.

\section{Author affiliation}

Adriaan van Klinken is Lecturer in African Christianity at the University of Leeds (UK). His research focuses on issues of gender, (homo)sexuality and public life

* Correspondence: School of Philosophy, Religion and History of Science, University of Leeds, 173 Woodhouse Lane, Leeds, LS2 9JT, UK. E-mail: a.vanKlinken@leeds.ac.uk This work is licensed under a Creative Commons Attribution License (3.0) Religion and Gender | ISSN: 1878-5417 | www.religionandgender.org | Igitur publishing 
in contemporary African Christianities, in particular Pentecostalism. He recently published Transforming Masculinities in African Christianity: Gender Controversies in Times of AIDS (Ashgate 2013).

\section{Introduction}

While preaching on 'biblical manhood' and 'biblical womanhood', Bishop Joshua H.K. Banda, a prominent Zambian Pentecostal pastor, once made an intriguing reference to George Orwell's Animal Farm. At the farm in this worldfamous allegorical novel, all animals are equal but some are more equal than others. According to the preacher, God's world is not like Orwell's animal farm: 'The world is God's world. He created them [that is, man and woman] male and female. ... There is an equality of personhood and status before God.' The reference to Orwell's animal farm in this sermon serves as a contrast, in order to emphasize what the preacher called the 'fundamental biblical principle of male-female equality'.

Interestingly, in the same sermon the preacher attempted to 'reconcile' and 'balance' this principle with yet another principle he also considered to be biblical, the idea of male headship. Thus, one could argue that in the gender ideology reflected here, the preacher's world is actually like Orwell's animal farm: man and woman may be equal, but man is still the head in marriage and the family. The sermon reflects what scholars of global Pentecostalism have called 'the Pentecostal gender paradox'. ${ }^{1}$ This paradox is commonly considered to illustrate the complex relationship of Pentecostalism in Africa and elsewhere to 'modernity'. In this article I seek to explore the relationship between African Pentecostalism and a major symbol of modernity, gender equality, and to reflect upon this from a postcolonial perspective.

Postcolonial perspectives entail a mode of analysis that is critically aware of, and concerned with 'the unequal and uneven forces of cultural representation involved in the contest for political and social authority within the modern world order'2, both in the historical context of colonialism and in the contemporary context of neo-colonialism and globalization. They also bear witness to local forms of resistance, subversion, variation and transformation in postcolonial contexts, vis-à-vis hegemonic Western discourses and politics. One such form is what Gayatri Spivak has called 'catachresis'. ${ }^{3}$ This term originally refers to grammatical misuse, but as Spivak uses the term it comes close to the meaning of appropriation, more specifically the deliberate, strategic and subversive (ab)use of an appropriate sign. As I will argue in this article, the seemingly

1 B. Martin, 'The Pentecostal Gender Paradox: A Cautionary Tale for the Sociology of Religion' in R.K. Fenn (ed.), The Blackwell Companion to the Sociology of Religion, Malden: Blackwell 2001, 52-66.

2 H.K. Bhabha, The Location of Culture, London and New York: Routledge 1994 (reprint 2010), 245.

3 See G.C. Spivak, 'Poststructuralism, Marginality, Postcoloniality and Value' in P. Mongia (ed.), Contemporary Postcolonial Theory: A Reader, Oxford: Oxford University Press 1996, 198-222.

Religion and Gender vol. 3, no. 2 (2013), pp. 240-258 
illogical and erroneous comparison between God's world and Orwell's animal farm in the above quoted sermon can be considered as a catachrestic gesture that interrupts the Western understanding of 'gender equality'. Responding to hegemonic discourses promoting a normative concept of gender equality equated with modernity, this gesture reveals, in the words of Homi Bhabha, the 'catachrestic, postcolonial translation of modernity', which I will argue is taking place in African Pentecostalism. ${ }^{4}$

\section{African Pentecostalism and Modernity}

A more than a century-old branch of Christianity, Pentecostalism is a fast expanding religious movement that is rapidly reshaping the face of the Christian religion globally, especially in 'the Global South'. ${ }^{5}$ Its growth has attracted much scholarly attention, and the study of Pentecostalism is an increasingly well-established field in Religious Studies and Anthropology of Religion. ${ }^{6}$ It is difficult to define Pentecostalism, because the term embraces widely diverse Christian churches and organizations. For that reason, Allan Anderson has proposed to speak about Pentecostalisms in the plural, to refer to 'a wide variety of movements scattered throughout the world that can be described as having "family resemblance". ${ }^{7}$ One of the regions where Pentecostalism is booming is sub-Saharan Africa, and a major issue in the study of African Pentecostalism is its relationship to modernity and globalization. 'What is distinctly new', says Birgit Meyer about Pentecostal churches in Africa, is 'their strong global inclination', expressed by using adjectives such as 'international' or 'global' in their names, which comes along with a discursive break with local cultural traditions. ${ }^{8}$ Pentecostalism, with its emphasis on the 'born-again' experience, advocates a complete break with the past, particularly the past of African indigenous religions and cultures. ${ }^{9}$

Scholars of global Pentecostalism have given much attention to the relationship between this religious movement and 'modernity'. It is frequently suggested that Pentecostalism in Africa and in other parts of the world advocates or represents modernity. In the words of David Martin, Pentecostalism reflects the 'major narrative of modernity' because it represents individual self-consciousness and agency, and underscores a new religious identity which implies a

4 Bhabha, The Location of Culture, 350.

5 A.H. Anderson, To the Ends of the Earth: Pentecostalism and the Transformation of World Christianity, Oxford: Oxford University Press 2013.

6 For example, see A.H. Anderson, M. Bergunder, A.F. Droogers and C. van der Laan (eds.), Studying Global Pentecostalism: Theories and Methods, Berkeley: University of California Press 2010.

7 A.H. Anderson, 'Varieties, Taxonomies, and Definitions' in Anderson et al. (eds.), Studying Global Pentecostalism, 15.

8 B. Meyer, 'Christianity in Africa: From African Independent to Pentecostal-Charismatic Churches' in Annual Review of Anthropology 33 (2004), 453.

9 B. Meyer, "'Make a Complete Break with the Past": Memory and Post-Colonial Modernity in Ghanaian Pentecostalist Discourse' in Journal of Religion in Africa 28:3 (1998), 317. 
break with social bonds and local cultural traditions. ${ }^{10}$ Writing specifically about Africa, Meyer notes that,

Pentecostalist discourse takes up the language of modernity as it spoke to Africans through colonization, missionization and, after Independence, modernization theory. Indeed, a clear analogy exists between the pentecostalist ... conceptualization of conversion in terms of a rupture with the past and modernity's selfdefinition in terms of progress and continuous renewal. ${ }^{11}$

Meyer and other scholars in the field further highlight the modern character of Pentecostalism by presenting it as a globalizing and transnational religious project, linked to neo-liberal capitalism. ${ }^{12}$ Of course, these scholars also realize that it is too simple to say that Pentecostalism advocates 'modernity', not least because such a claim assumes a singular (Western) notion of modernity, when it is increasingly acknowledged that there are multiple modernities in our contemporary globalizing world. ${ }^{13}$ Indeed, Africanist scholars talk about 'African modernities' 14 in the plural, or about 'multiple trajectories of modernity'. ${ }^{15}$ Second, anthropological research shows that the relation of Pentecostalism to what is often considered as 'modern' is rather complex and ambiguous. In the words of Joel Robbins,

The question of Pentecostalism's relation to modernity is a persistent one precisely because it is not easy to answer. From some perspectives, Pentecostalism clearly looks modern. Its emphasis on discontinuity, for example, maps neatly onto modernist ideas about the need for radical change and about transformation as progress. Yet from other vantage points, it equally looks to be something other than modern. Its frank supernaturalism and commitment to ontological preservation, to take two cases in point, give it a 'premodern' cast, while its wide dispersal of authority and the network quality of its social organization have led some to classify it as postmodern. ${ }^{16}$

The complexity and ambiguity of Pentecostalism's relation to modernity becomes particularly clear in the domain of gender, as I will explore below. My interest here is in the Pentecostal trajectory of modernity in African societies. I am aware of the problems related to the concept of 'modernity', particularly the problem

10 D. Martin, On Secularization, Aldershot and Burlington: Ashgate 2005, 141-154.

11 Meyer, 'Make a Complete Break with the Past', 317.

12 A. Corten and R. Marshall-Fratani (eds.), Between Babel and Pentecost: Transnational Pentecostalism in Africa and Latin America, Bloomington: Indiana University Press 2001; B. Meyer, 'Pentecostalism and Globalization' in Anderson et al. (eds.), Studying Global Pentecostalism, 113-130; B. Meyer, 'Pentecostalism and Neo-Liberal Capitalism: Faith, Prosperity and Vision in African Pentecostal-Charismatic Churches' in Journal for the Study of Religion 20:2 (2007), 5-28.

${ }^{13}$ S.N. Eisenstadt (ed.), Multiple Modernities, New Brunswick: Transaction Publishers 2002.

${ }^{14}$ J. Deutch, P. Probst and H. Schmidt (eds.), African Modernities: Entangled Meanings in Current Debate, Oxford: Heinemann 2002.

${ }^{15}$ P. Geschiere, B. Meyer and P. Pels, 'Introduction' in P. Geschiere, B. Meyer and P. Pels (eds.), Readings in Modernity in Africa, London: The International African Institute 2008, 5 .

${ }^{16} \mathrm{~J}$. Robbins, 'Anthropology of Religion' in Anderson et al. (eds.), Studying Global Pentecostalism, 168.

Religion and Gender vol. 3, no. 2 (2013), pp. 240-258 
of defining 'modernity'. Dominant accounts of the emergence and development of 'modernity' have been critiqued from postcolonial perspectives for being Eurocentric and neglecting the contribution of 'non-Western others' to modernity. ${ }^{17}$ I follow Geschiere, Meyer and Pels in their genealogical approach, which does not seek to define modernity but rather understands it as an 'historical phenomenon that is still evolving' and that gives rise to contradictions and ambivalences. ${ }^{18}$ Such an approach is particularly relevant in Africa. From the 19th and 20th century period of colonization and missionary activity to the post-independent era of 'development', 'modernization', and neo-liberal capitalism, different African societies have been subject to dominant Western discourses of modernity and have incorporated and negotiated these in different and complex ways. Pentecostalism can be considered to be a recent example of the negotiation of modernity in Africa. As Rijk van Dijk succinctly puts it, 'Pentecostalism in modern African societies is both a debate within modernity as well as a discourse on modernity. ${ }^{19}$ The contradictions and ambivalences in the relationship between Pentecostalism and modernity become visible, among others, in its gender ideology that is both modern and anti-modern at the same time.

\section{Gender in African Pentecostalism}

There is quite a substantial body of literature on gender in African Pentecostalism, generally focusing on women but increasingly also taking men and issues of masculinity into account. ${ }^{20}$

The central question in much of this literature, according to Robbins, is 'whether or not Pentecostalism has generated among converts outside the West something that resembles Western notions of gender equality'. ${ }^{21}$ I will return below to Robbins' rather Western-centric formulation of the problem. For now, I simply note that this question is difficult to answer because the complexity and ambiguity of Pentecostalism's relation to modernity becomes particularly clear in the domain of gender. The vignette with which I opened this article is an illustration here: in one and the same sermon it is argued that man and woman are equal and that man is the head of woman. Even though it is stated that God's world is not an animal farm, in fact it is clear that the egalitarian tendency does not eliminate, but rather is combined with, a gender hierarchy in which men still have precedence over women. This reflects the ambiguity of Pentecostal gender discourse, or the 'Pentecostal gender paradox'.

\footnotetext{
17 See G.K. Bhambra, Rethinking Modernity: Postcolonialism and the Sociological Imagination, New York: Palgrave Macmillan 2007.

18 Geschiere, Meyer and Pels, Introduction, 2.

${ }^{19}$ R. van Dijk, 'Time and Transcultural Technologies of the Self in the Ghanaian Pentecostal Diaspora' in A. Corten and R. Marshall-Fratani (eds.), Between Babel and Pentecost: Transnational Pentecostalism in Africa and Latin America, Bloomington: Indiana University Press 2001, 218.

${ }^{20}$ Cf. J.E. Soothill, Gender, Social Change and Spiritual Power: Charismatic Christianity in Ghana, Leiden: Brill 2007; A.S. van Klinken, Transforming Masculinities in African Christianity: Gender Controversies in Times of AIDS, Farnham and Burlington: Ashgate 2013.

${ }^{21}$ Robbins, 'Anthropology of Religion', 169.
} 
The paradox, according to Martin, is that Pentecostal forms of Christianity on the one hand have 'a modernizing egalitarian impulse': women are religiously empowered by the notion of spiritual gifts and they benefit from the discursive institution of a family discipline through which men are 'domesticated'. On the other hand, however, Pentecostal gender discourse embraces traditional Christian notions of gender that are embedded in patriarchal lines of thought. Thus:

an unresolved tension remains between the de jure system of patriarchal authority in church and home and the de facto establishment of a way of life which decisively shifts the domestic and religious priorities in a direction that benefits women and children while morally restraining the traditional autonomy of the male and the selfish or irresponsible exercise of masculine power. ${ }^{22}$

From a gender-critical perspective one may ask whether it is really a paradox that is pointed out here: to make the domestic arena a more comfortable place for women does not necessarily pose a challenge to patriarchy but on the contrary it may well confirm the patriarchal division of labour. There needs to be more evidence of the 'egalitarian impulse' in Pentecostalism to have a convincing account of a gender paradox.

Martin's above quoted essay is on Pentecostalism in general, and her references are mainly to studies conducted in the Americas. ${ }^{23}$ However, the ambivalent nature of Pentecostal gender discourse is also evident in studies of gender in African Pentecostalism. Some of these studies are rather positive about the contribution that Pentecostalism is making towards gender equality and the empowerment of women. They mainly refer to the Pentecostal belief that the gifts of the Holy Spirit are endowed upon all born-again believers, which allows women to take up leadership roles in the church. ${ }^{24}$ Thus, Kwabena AsamoahGyadu observes an 'innovative gender ideology' that endows women with 'a new pastoral and theological authority in a Christian context'. ${ }^{25}$ Likewise, Ogbu Kalu suggests that 'the complementarity in the Spirit between men and women...could provide an exit from the shackles of patriarchy', and he insists that African feminist theologians should acknowledge and appreciate the contribution that Pentecostalism is making to the transformation of gender relations. ${ }^{26}$ From a study on female-led Pentecostal organizations in Kenya, Damaris Parsitau concludes that 'women clergy and laity are using the new faith as a space for struggle, for liberation, for dislocating culture and patriarchy and to contest leadership and public life' ${ }^{27}$

\footnotetext{
22 Martin, 'The Pentecostal Gender Paradox', 54.

${ }^{23}$ Such as E.E. Brusco, The Reformation of Machismo: Evangelical Conversion and Gender in Colombia, Austin: University of Texas Press 1995.

${ }^{24}$ M. Frahm-Arp, Professional Women in South African Pentecostal Charismatic Churches, Leiden: Brill 2010; B.M. Sackey, New Directions in Gender and Religion: The Changing Status of Women in African Independent Churches, Lanham: Lexington Books 2006.

25 J.K. Asamoah-Gyadu, African Charismatics: Current Developments within Independent Indigenous Pentecostalism in Ghana, Leiden: Brill 2004, 57.

${ }^{26}$ O.U. Kalu, African Pentecostalism: An Introduction, Oxford: Oxford University Press 2008, 161; see also 165.

27 D. Parsitau, 'Agents of Gendered Change: Empowerment, Salvation and Gendered Transformation in Urban Kenya' in D. Freeman (ed.), Pentecostalism and Development: Churches, NGOs and Social Change in Africa, New York: Palgrave Macmillan 2012, 219.
}

Religion and Gender vol. 3, no. 2 (2013), pp. 240-258 
Other scholars are more sceptical. Jane Soothill, for example, wonders whether the presence of female founders does in fact empower other women in the movement, and whether the democratization of charisma is really gender neutral. ${ }^{28}$ She also points to the problematic tendency to conflate the spiritual empowerment of women with social empowerment, which she observes in the work of Kalu and Asamoah-Gyadu. ${ }^{29}$ Some African feminist scholars have been quite critical about the transformations in the configuration of gender in Pentecostal circles. South African feminist theologian Sarojini Nadar argues that Pentecostal interpretations of the Bible actually reinforce traditional forms of gender inequality, by promoting male headship and female submission in marital relationships. ${ }^{30}$ Likewise, social scientist Rekopantwse Mate, in a study of gender and modernity in Zimbabwean Pentecostalism, concludes that 'if indeed "born again" Churches are to help adherents to cope with modernity, their version of modernity calls for stricter controls on women using religious ideology. For gender relations they envision a modernity where women are subordinate to men.' ${ }^{\prime 31}$

All these findings and conclusions concerning gender in African Pentecostal circles are clearly at tension with each other. This may partly be because 'African Pentecostalism' is far from homogenous. In different strands of Pentecostal Christianity, and in different African contexts, there will definitely be different theological and gender ideological emphases that affect the place and space for women and the configuration of gender relations. To see whether the conflicting conclusions quoted above are really contradictory, we would need to know more about the specific nature of the observed empowering and transformative aspects of Pentecostalism. How does spiritual empowerment relate to social empowerment? (Or is the distinction between 'the spiritual' and 'the social' problematic anyway, because of its underlying secular assumption?) How do changes in the domestic sphere relate to, and impact on the wider societal and public sphere? Do these transformations really challenge patriarchal structures in the family and society? These questions call for further and more systematic empirical work. At this moment I want to suggest that the above-mentioned conflicting conclusions might also reveal something of the ambivalent and possibly paradoxical nature of African Pentecostal gender discourse, due to the complex relationship of Pentecostalism to 'modernity'.

\section{A Zambian Pentecostal Bishop Preaching Gender Equality}

Through an analysis of several sermons preached by the already quoted Zambian Pentecostal pastor, Bishop Joshua H.K. Banda, I will explore in more detail the ambivalences in an African Pentecostal gender discourse, specifically the

28 J.E. Soothill, 'The Problem with "Women's Empowerment": Female Religiosity in Ghana's Charismatic Churches' in Studies in World Christianity 16:1 (2010), 87.

${ }^{29}$ Soothill, 'The Problem with "Women's Empowerment"', 96.

${ }^{30}$ S. Nadar, '"The Bible Says!" Feminism, Hermeneutics and Neo-Pentecostal Challenges' in Journal of Theology for Southern Africa 134 (2009), 131-146.

${ }^{31}$ R. Mate, 'Wombs as God's Laboratories: Pentecostal Discourses of Femininity in Zimbabwe' in Africa 72:4 (2002), 566. 
conceptualization of gender equality. I focus on sermons because these are an important means through which the mainly oral Pentecostal theologies are developed and transmitted, not only to the congregation but often - through the use of modern media - also to a wider public. The sermon, furthermore, is a central part of a Pentecostal church service, and is in itself a discursive space in which the pastor addresses and engages with his (sometimes, her) congregation, using modes of critique, moralization, and appeals for change.

I am not claiming that Banda is representative of African Pentecostal leaders, or that his sermons are representative of African Pentecostal discourse in general. Such claims would be problematic, given the enormous diversity within Pentecostalism. Nonetheless, Banda's sermons certainly offer some insight into the complexity of gender discourse in African Pentecostal circles. My analysis is based on a series of sermons entitled Fatherhood in the 21st Century that was preached in 2008 by Banda at his church, Northmead Assembly of God, and that was also broadcast in Zambia and the wider Southern African region through the church's TV programme The Liberating Truth. When I first arrived in the church to start my research in October 2008, the series had just been delivered, but I was able to obtain copies of the sermons on DVD.

Northmead Assembly of God is a prominent Pentecostal church in Lusaka, the capital city of Zambia, mainly attracting people from the growing urban middle class. Banda himself is a leading figure in the Zambian Pentecostal movement. He preached this series because he wanted to address the 'distortion of manhood' that he perceives in society and to promote a vision of 'biblical manhood' among men. I do not aim to present a full case study of this sermon series, because I have offered an extensive analysis, specifically of their conceptualization of masculinity, elsewhere. ${ }^{32}$ The analysis presented here focuses instead on the way gender equality is conceptualized.

Elaborating on the 'distortion of manhood' in Zambia, Banda identifies several issues related to men and dominant forms of masculinity about which he is seriously concerned. These issues vary from men's extramarital sexual relationships, their excessive intake of alcohol, the lack of male involvement in the family and the tendency among men to dominate and use violence against women, to the lack of religious commitment and church involvement among men and men's failing political leadership in society. In the seven sermons of the series, Banda elaborates extensively on all these issues that, in his opinion, illustrate how manhood has 'distorted' from the original idea of God in creation, and he calls upon men to change their lifestyle and to become truly born-again Christian men.

In the sermons Banda presents an alternative version of manhood, called 'biblical manhood' - a concept derived from some American evangelical writers $^{33}$ - which is first and foremost informed by the ethical-theological notion of

\footnotetext{
32 See Van Klinken, Transforming Masculinities, Chapter 3.

33 In the sermons, Banda quotes from two chapters in the book J. Piper and W. Grudem (eds.), Recovering Biblical Manhood and Womanhood: A Response to Evangelical Feminism, Wheaton: Crossway Books 1991: J. Piper, 'A Vision of Biblical Complementarity: Manhood and Womanhood Defined According to the Bible' (31-59) and R.C. Ortlund, Jr., 'Male-Female Equality and Male Headship' (95-112). Both authors and the editors of the volume are involved in the American conservative-evangelical Council on Biblical Manhood and Womanhood (https://www.cbmw.org/).
} 
responsibility. He also presents Jesus Christ, 'the second Adam', as having the spiritual powers to liberate men from the failures associated with manhood since the fall of the first Adam into sin. These sermons can be considered as a discursive example of what Elizabeth Brusco, in a study in Columbia, has called the 'reformation of machismo', a transformation of masculinity that Pentecostal Christianity seeks to bring about as part of its socio-political programme. ${ }^{34}$

In view of our interest in gender equality, it is important to note that Banda explicitly refers to male domination and superiority over women as an expression of the 'distortion of manhood'. In his sermons, he critically addresses men for their attitudes of superiority over women and their disrespect towards women, the use of violence against their wives and the authoritarian way in which they practise leadership in marriage and the family. According to Banda, the pattern of domination is characteristic of men and masculinities in Zambia generally, and he explains this from the 'push for male chauvinism' that he considers to be typical of 'African culture'. ${ }^{35}$ With this criticism of an African hegemonic masculinity, Banda confirms the findings of Soothill who, on the basis of a study in Ghana, observes that Pentecostalism 'represents a critique of "African culture" and what is seen as its tradition of sexual inequality that favours men and disrespects women'. ${ }^{36}$

The 'break with the past' that is part of born-again conversion thus has particular implications for male converts. For them, this break 'is conceptualised in terms of their attitudes towards women and the rejection of role models established by their fathers' ${ }^{37}$ In Pentecostalism, the supposed traditional ideas about the superior status of men are rejected as these are believed to be responsible for the moral and social crises that African families and societies are facing. Banda's association of 'African culture' with male chauvinism and dominance is somewhat ironic because, historically, many of the groups populating the area now called Zambia were organized as matrilineal societies where women held central social, economic, political and religious roles. This has changed dramatically in recent centuries, not least because of colonialism, missionary Christianity and the incorporation of the Zambian economy into the capitalist world market. ${ }^{38}$ Thus, it seems that Banda's general critique of male dominance, informed by his concern about concrete problems such as the high levels of HIVIAIDS and domestic and sexual violence against women, applies more to the contemporary situation in Zambia that is the result of relatively recent processes of sociocultural and economic change, than to the cultures of pre-colonial 'Zambian' societies.

In order to correct and overcome men's tendency towards domination and superiority, Banda emphasizes the equality of men and women, speaking about an 'equality of personhood' and an 'equality of status before God'. It is in this context that he makes the above quoted reference to Orwell's Animal Farm. Thus, Banda acknowledges the fundamental equality of men and women in

\footnotetext{
${ }^{34} \mathrm{Cf}$. Brusco, The Reformation of Machismo.

35 Interview with Bishop Joshua H.K. Banda, Lusaka: 6 November 2008.

${ }^{36}$ Soothill, Gender, Social Change and Spiritual Power, 187.

37 Ibid., 189.

38 T. Rasing, The Bush Burnt, the Stones Remain: Female Initiation Rites in Urban Zambia, PhD thesis African Studies Centre, Leiden, 2001.
} 
God's creation. Referring to Genesis 1:27, which reads that humankind is created as male and female in God's image, he rhetorically asks in a sermon: 'So why do men act as if they are the only ones made in the image of God? Both men and women are made in God's image!'39 On this theological basis he actively addresses domestic and sexual violence against women, and men's tendency to subordinate and oppress women. He preaches, for example:

What we have seen most times is male domination. And it stinks in the nostrils of God. It is a distortion of God's order. Because male domination implies that the woman is less than the man, but that's not biblical. Genesis 1:26 says: Let them rule, both as male and female. They have dominion together, not over each other but over the earth. Together we govern the earth on behalf of heaven. ${ }^{40}$

Where traditional Christian readings of Genesis 1:26 have been critiqued by feminist scholars for applying the notion of dominion over the earth only to mankind, this Pentecostal preacher has no problem with an inclusive reading. The 'rule over the earth', translated by Banda as 'playing our role in society', is considered a task of humankind, both male and female. Making the consequences of this view more explicit, he points out that men and women should have equal opportunities in society: women, just like men, should have access to education and formal employment and should be encouraged to pursue a professional career. In this way, he is able to accommodate modern developments in Zambia's growing urban middle class, where women indeed are increasingly involved in formal employment and are pursuing professional careers, and where women - just as in pre-colonial societies - participate and contribute actively to the economy.

Banda also warns men that they have to accept women's leadership in the companies and organizations they are working in, up to the highest political level, because one day a woman might become president of Zambia. He further translates the notion of equality into the intimate sphere of marital relationships: these should be defined by 'love, companionship and commitment' ${ }^{41}$, and he insists that men should spend 'quality time' with their wives and satisfy their wives' sexual needs. ${ }^{42}$ Moreover, on a more societal level, the sermons reveal Banda's concern about Zambian women being deeply affected by poverty, AIDS and violence. This concern, and his subsequent emphasis on 'male-female equality', indicates that Banda is sympathetic to the promotion of women's socioeconomic rights and the empowerment of women that in recent years has been pushed by the Zambian government and by Non-Governmental Organizations as part of a broader development agenda. In all this, the sermons clearly reflect - in the words of Bernice Martin - the 'modernizing egalitarian impulse' of Pentecostalism. ${ }^{43}$ It is crucial to note here that in Banda's case this impulse is not limited to the domestic sphere, as Martin suggests for Pentecostalism in general

\footnotetext{
39 Joshua H.K. Banda, Fatherhood in the 21st Century - Part 4, Lusaka: Northmead Assembly of God. In the following references to sermons in the series, I will shorten this to 'Banda, Fatherhood, part x'.

40 Banda, Fatherhood, part 6.

41 Banda, Fatherhood, part 1.

42 See also Soothill, Gender, Spiritual Power and Social Change, 202-203.

43 Martin, 'The Pentecostal Gender Paradox', 54.
} 
and is also the case in the American evangelical literature that Banda quotes, but also concerns the wider societal spheres, thus contributing to women's social empowerment. This poses a more fundamental challenge to structures of patriarchal authority in society than transformations that are only concerned with the domestic realm. Further, as much as this impulse is modernizing, it may also be interpreted - despite Banda's own critique of "African culture" - as a correction of processes of change in colonial and postcolonial Zambia that have reinforced male dominance in domestic, social, political and economic domains.

Since our analysis is concerned with sermons, the egalitarian impulse under discussion here is discursive. Whether and how this transformative discourse indeed effects change is a different question and one that I cannot explore here because of limitations of space. However, the least I can say is that, at a discursive level, this impulse is not only reflected in Banda's sermons but also in the conversion narratives of men attending his church. ${ }^{44}$ Moreover, it is noteworthy that several female church members expressed to me their appreciation of the sermon series because it corresponded with their own ideals of marital and broader gender relations and their own expectations of their husbands, and they hoped men would take the bishop's message seriously.

\section{Reconciling Equality and Headship}

So far, we seem to have met a Pentecostal preacher who has embraced the modern gospel of gender equality and who seeks to nurture more gender equitable men. However, as one may expect, there is a 'but'. Despite the emphasis on male-female equality, Banda also promotes male headship and leadership in his sermons, which presents a real gender paradox. He explicitly states that 'biblical manhood clearly shows that the role of headship has been given to men', and he cautions women in the church by saying, 'Don't try to fight that, it is God's order!'45

It is important to grasp how Banda understands male headship in a way that, in his opinion, is compatible with the idea of male-female equality. First, he dissociates 'headship' from the connotations of superiority, dominance and power, literally stating that 'male headship does not mean male domination' ${ }^{46}$ Second, following the definition of 'biblical manhood' from the American Baptist pastor John Piper, he alternatively defines headship in terms of a man's 'benevolent responsibility to lead'. ${ }^{47}$ The word 'benevolent' is a qualification, Banda points out: male headship is a form of 'servant leadership' that is concerned with strengthening others (in this case, women) and encouraging them to play their role. Third, in a significant divergence from the American evangelical literature he extensively quotes in some of the sermons, Banda limits the scope of male

${ }^{44}$ A.S. van Klinken, 'Men in the Remaking: Conversion Narratives and Born-Again Masculinity in Zambia' in Journal of Religion in Africa 42:3 (2012), 215-239.

45 Banda, Fatherhood, part 6.

${ }^{46}$ Banda, Fatherhood, part 6.

47 Banda, Fatherhood, part 3 and 4. For Piper's definition of biblical manhood that is quoted by Banda, see Piper, 'A Vision of Biblical Complementarity', 36. 
headship: it only applies to the marital sphere. ${ }^{48} \mathrm{He}$ is also much more unequivocal in his notion of male-female equality. ${ }^{49}$ In the public sphere, according to Banda, men and women are equal - women can be pastors in church, can be in charge of companies and can even become president - but in the domestic sphere women have to respect their husbands' headship. All this shows that Banda's sermons are not so much a neo-traditional or conservative response to modern changes in gender relations (as is the case with the American evangelical literature he refers to), but have some interesting twists and in fact make a relatively progressive contribution to such changes in the context of postcolonial Zambia. ${ }^{50}$

Although Banda does not completely give up the material dimension of male headship, that is, that men have to provide the material needs of their families, he tends towards a more symbolic definition. Thus, he points out that men have the 'primary responsibility to provide' for the family, but that women can also make a significant contribution. Headship, in his account, primarily means that 'the man bears the primary responsibility to lead the partnership in a Godglorifying manner or direction', in other words, men have to provide 'spiritual leadership' in marriage and the family. ${ }^{51}$ Thus, Banda's sermons are an illustration of Soothill's argument that in Pentecostal Christianity:

male headship does not mean that men are superior to women, or more precisely, that the husband is superior to the wife. The concept of superiority of the man over the woman is presented as an African traditional belief.... In born-again Christianity then, the concept of male headship is redefined in terms of 'love' and 'sacrifice', and the primary focus of a man's life shifts from self to partner. ${ }^{52}$

Taking seriously this redefinition and its productive effects among men, I have argued elsewhere that the Pentecostal rhetoric on male headship can be analysed and interpreted in terms of male agency. ${ }^{53}$ It is precisely through this transformative agential understanding of headship that men are 'domesticated', and this domestication of men, according to Martin and others, is key to the Pentecostal family discipline that is benefiting women. ${ }^{54}$

Apparently, Banda is aware of the ostensible tension between the concepts of 'equality' and 'headship'. He devotes a whole sermon to an attempt to 'reconcile this male-female equality with the biblical principle of male headship' ${ }^{55}$ It is not my task here to evaluate whether this attempt is successful. What is

\footnotetext{
${ }^{48}$ This is in contrast with Piper, ibid., and Ortlund, 'Male-Female Equality and Male Headship', who give male headship a much broader scope and present it as a general principle in male-female relationships.

${ }^{49}$ For example, he does not follow Ortlund (ibid., 100) who suggests that social inequalities, including gender inequality, are part of God's design.

${ }^{50}$ Cf. Van Klinken, Transforming Masculinities, 185-188.

51 Banda, Fatherhood, part 6.

52 Soothill, Gender, Social Change and Spiritual Power, 191 and 193.

53 A.S. van Klinken, 'Male Headship as Male Agency: An Alternative Understanding of a "Patriarchal" African Pentecostal Discourse on Masculinity' in Religion and Gender 1:1 (2011), 103-124.

${ }_{54}$ Martin, 'The Pentecostal Gender Paradox', 54. See also Brusco, The Reformation of Machismo.

55 Banda, Fatherhood, part 6.
} 
important to acknowledge is that Banda seriously believes that both concepts have to be and can be reconciled in a harmonious gender ideology that is in line with 'God's order of creation'. What may seem contradictory and illogical to the feminist or gender-critical scholar, apparently makes sense in the worldview of this Pentecostal preacher. This illustrates the Pentecostal gender paradox par excellence. The creative space opened up in this paradox can be used in different ways, emphasizing different sides of the paradox, but is used by Banda primarily to redefine male headship so that it 'domesticates' men and allows for women's social empowerment.

\section{A Catachrestic Translation of Gender Equality}

More than the question of how to evaluate Banda's ambiguous gender ideology from a gender-critical perspective, what interests me here is how this Pentecostal gender ideology can be understood from a postcolonial perspective. Such a perspective acknowledges that Banda speaks from what Achilles Mbembe has called 'the postcolony', and that African Pentecostalism more generally has emerged in this 'postcolony'. With this term, Mbembe refers to societies that have gone through a specific historical trajectory, 'emerging from the experience of colonization and the violence which the colonial relationship involves', and where past and present are intertwined and entangled in multifarious ways. ${ }^{56}$

Pentecostalism is one of the most prominent religious movements proliferating in Africa today. Explaining this religious vitality, Mbembe points out that in the socio-cultural dynamics of the African postcolony, these movements 'constitute visible, if ambiguous, sites where new normative systems, new common languages, and the constitution of new authorities are being negotiated'. ${ }^{57}$ Gender, deeply affected and destabilized by the history of colonialism and missionary Christianity, by processes of urbanization and globalization, and by post-independent challenges such as the HIV epidemic, is one of the major fields in the African postcolony where these religious movements seek to exert influence. As outlined above, Pentecostalism in this context is often considered to be a 'modernizing' movement because of its push for egalitarianism in words and/ or in practice.

The case study of Banda's sermons has clearly shown this push for egalitarianism. However, it is also clear that the same sermons demonstrate the complex and ambiguous meaning of 'gender equality' in an African Pentecostal setting. This is part of the Pentecostal gender paradox, but in my opinion this paradox and the way it is construed in Banda's sermons has a particular significance from a postcolonial perspective. In his sermons, Banda discusses the meaning

\footnotetext{
56 A. Mbembe, On the Postcolony, Berkeley: University of California Press 2001, 102. In response to critics, Mbembe has emphasized that the concept of the postcolony does not so much refer to a (homogenized) historical and social context in Africa, but should be read as a form or figure, 'a Figure of a fact - the fact of brutality, its forms, its shapes, its markings, its composite faces, its fundamental rhythms and its ornamentation.' (A. Mbembe, 'On the Postcolony: a Brief Response' in African Identities 2:2 (2006), 151.) 57 Ibid., 93.
} 
of what he calls 'male-female equality' in contrast to Western and feminist understandings of gender equality. Where he, on the one hand, is critical of 'African culture' for its presumed tendency towards male chauvinism, on the other hand he also criticizes feminist movements which reject the idea of male headship: 'Feminist movements have been wrong in our day and time; to fight this order is wrong. ${ }^{\prime 58}$ Feminist movements, in Banda's opinion, impose 'Western standards' of gender relations on Africa and they neglect the 'biblical standards' in which male and female are equal but yet have different roles. ${ }^{59}$ Though he is aware that feminism is not exclusively a Western project and that there are also African feminist movements, in his opinion the standards these movements promote are Western. Of course there is a high degree of selectivity in labelling certain values as 'Western' and then to reject them. Banda has no problem with adopting notions from an American evangelical discourse, which can also easily be labelled as 'Western'. This selectivity makes the criticism of feminism for its 'Western' conception of gender equality not very convincing. However, there may be a sense of truth in it.

There is a normative discourse about gender equality, a discourse that has largely emerged as a result of feminist political movements and that influences the politics and policies of a wide range of governmental, non-governmental and international organizations and development agencies. Although there is an ongoing discussion about the understanding of gender equality among feminist theorists and gender studies scholars, the concept of gender equality is generally associated with Western Enlightenment principles of autonomy and individuality, as critics such as Saba Mahmood have pointed out. ${ }^{60}$ This dominant conception of gender equality, that is also reflected in much of the discourse on gender and development, has become a central symbol of a generally secular Western model of modernity that, in the era of globalization, is exported and affects socio-cultural change all over the world. ${ }^{61}$ The essay 'Change Among the Gatekeepers: Men, Masculinities and Gender Equality in the Global Arena' by the influential masculinity theorist R.W. Connell can serve as an example here. In this essay, Connell envisions transformations in masculinity on a world-wide scale, with men increasingly being involved in 'gender-equality reform'. Connell refers critically to religious ideologies and institutions as forces opposing this transformation through an 'ideological defense of male supremacy' and the promotion of 'conservative gender ideology'. ${ }^{62}$ The essay assumes that it is clear what gender equality is and then suggests that it is either supported (by progressive liberals) or resisted (by conservatives). From this perspective, Banda can be considered, at best, as an African Pentecostal pastor stuck halfway to modernity: he adopts the idea of equality of men and women, but at the same time still adheres to some traditional religious ideas about male headship. More

\footnotetext{
${ }^{58}$ Banda, Fatherhood, part 6.

59 Interview with Joshua H.K. Banda, Lusaka: 6 November 2008.

60 S. Mahmood, Politics of Piety: The Islamic Revival and the Feminist Subject, Princeton and Oxford: Princeton University Press 2005.

${ }^{61}$ R. Inglehart and P. Norris, Rising Tide: Gender Equality and Cultural Change Around the World, Cambridge: Cambridge University Press 2003.

${ }^{62}$ R.W. Connell, 'Change Among the Gatekeepers: Men, Masculinities, and Gender Equality in the Global Arena' in Signs: Journal of Women in Culture and Society 30:3 (2005), 1801-1802.
}

Religion and Gender vol. 3, no. 2 (2013), pp. 240-258 
likely, he might be seen as yet another neo-conservative religious leader who in the end appears to defend male supremacy and thus resists 'gender equality reform'. From this perspective, Pentecostalism will more generally be seen as a religious movement hindering the necessary reforms for gender equality in Africa.

Following the above-mentioned insight that modernity, however, is not a single Western project but that there are multiple and contesting forms of modernity which relate to each other in dynamic and complex ways, it can be argued that Banda contributes to the construction of alternative modernities in African Pentecostal circles. His sermons show how Pentecostalism in Africa intervenes, to use a phrase of Bhabha, in the 'ideological discourses of modernity' that are imposed on African societies, even in the postcolonial era. This intervention may take a different shape than Bhabha imagined, because it is not the radical or progressive type of revisions of a hegemonic project of modernity that he has in mind.$^{63}$ However, it clearly is a critical revision around issues of cultural difference and social authority - a revision that is emancipatory for the African Pentecostal subject who in the antagonistic dominant narrative of modernity is doubly 'othered': because of being African and being Pentecostal.

At this point I would like to argue that the Pentecostal intervention in the Western narrative of modernity, specifically its normative concept of gender equality, can be considered as an example of catachresis. The term 'catachresis' in postcolonial theory was coined by Gayatri Spivak to conceptualize 'the process by which the colonized take and reinscribe something that exists traditionally as a feature of imperial culture'. ${ }^{64}$ Spivak refers, for example, to the claims that are made from postcolonial societies to the names and languages that are the legacy of the European Enlightenment, such as sovereignty, constitutionality, self-determination, nationhood and citizenship. Such claims, she writes, 'are catachrestical claims, their strategy a displacing and seizing of a coding of value' and they 'show that the alternative to Europe's long story generally translated as "great narratives" - is not only short tales (petit récits) but tampering with the authority of storylines'. ${ }^{65}$ The normative conception of gender equality, as I have mentioned above, is also part of the Enlightenment legacy, and in African Pentecostal circles this concept is adopted, appropriated and negotiated in a way that is clearly at tension with the original meaning of the term. From the perspective of a normative Western modernity, Pentecostal discourse violates or even abuses the notion of gender equality. After all, according to its 'proper' or classical meaning, gender equality means a radical equality of men and women, with equal access to power and knowledge. Thus, when Banda seriously attempts to 'reconcile' male-female equality with the idea of male headship, he makes a catachrestical claim on the Western modern narrative of gender equality. In these Pentecostal sermons, we see 'the insertion and the reinscription of something which does not refer literally to the correct narrative'. ${ }^{66}$ Because gender equality is a major symbol of the Western narrative

\footnotetext{
63 Bhabha, The Location of Culture, 245.

${ }^{64}$ B. Ashcroft, G. Griffiths and H. Tiffin, Post-Colonial Studies: The Key Concepts, London: Routledge 2007, 30.

65 Spivak, 'Poststructuralism, Marginality, Postcoloniality and Value', 207.

${ }^{66}$ Gayatri Spivak, quoted from Ashcroft, Griffiths and Tiffin, Post-Colonial Studies, 30.
} 
of modernity, the catachresis of gender equality in Pentecostal circles can be seen as illustrative of the relationship of African Pentecostalism to modernity at large. It can be argued that Pentecostalism in Africa represents what Bhabha has called a 'catachrestic, postcolonial translation of modernity'. ${ }^{67}$ With his language about the postcolonial translation of modernity, Bhabha seeks to deconstruct teleological time, the idea that modernity is a symbol of the continuity of progress, a Western narrative posed as History. Highlighting the contradictory and unresolved character of the project of modernity, Bhabha is concerned with modernity as 'a sign of the present'. Here, 'the "value" of modernity is not located, a priori, in the passive fact of an epochal event or idea - of progress, civility, the law - but has to be negotiated within the "enunciative" present of the discourse. ${ }^{\prime 68}$ In this way, modernity is open to postcolonial translation and its values are catachrestically seized.

It is not difficult to employ Bhabha's rather dense language and relate it to Pentecostalism in Africa. As a vibrant religious movement in postcolonial Africa that discursively distinguishes itself explicitly from Africa's 'traditional' past, Pentecostalism clearly is 'a sign of the present'; it represents modernity precisely by the fact that it negotiates and contests the values associated with the dominant Western narrative of modernity. To put it in the words of Spivak quoted above, Pentecostalism tampers with the authority of storylines, in this case the storyline of modernity - after all, if the nebulous concept of modernity is about anything it is about the authority of a storyline, as we just have seen. In a catachrestic gesture, Pentecostalism adopts and adapts, or tampers with, the Western narrative of modernity, and in this way it comes to present an alternative form of modernity. Hence, Pentecostalism raises the questions as to what defines 'modernity' and who determines what counts as 'modernity' in a postcolonial and globalizing world. Feminist and gender-critical scholars trained in postcolonial criticism tend to be sensitive to these questions as long as they are abstract and general. However, as soon as such questions relate to the modern concept of gender equality, they become uncomfortable and unsettling because they challenge not only a key value in Western narratives of modernity, but also a norm that explicitly or implicitly underlies and informs our scholarship. Precisely this discomforting and troubling effect, however, may be part and parcel of catachresis as a creative and critical appropriation and reinscription of a normative Western concept in a postcolonial context.

Spivak, Bhabha and other postcolonial theorists consider catachresis to be a form of postcolonial agency. This is because catachrestical claims to concepts that are part of Western traditions often assert that similar concepts existed in indigenous pre-colonial traditions, thus contesting the superiority and authority of Western narratives. However, in the case of catachresis in African Pentecostal circles, we have not only seen how Western hegemonic standards are critically adapted, which indeed reveals an aspect of postcolonial agency, but also how indigenous African traditions are strongly criticized. This clearly is a contra-example of postcolonial agency and makes Pentecostalism vulnerable to the criticism that it perpetuates colonial portrayals of African culture. Instead of a postcolonial reclamation of local cultural traditions vis-à-vis the West, in

${ }^{67}$ Bhabha, The Location of Culture, 350.

68 Ibid., 347.

Religion and Gender vol. 3, no. 2 (2013), pp. 240-258 
Pentecostalism we see a discursive rejection of these traditions and an orientation, though catachrestical, towards Western narratives of modernity. The distinction between 'postcolonial' and 'decolonial' can be helpful here: Pentecostalism might present a form of postcolonial resistance to certain hegemonic Western norms, but it does not present a decolonizing practice, it does not contribute to what Ngũgĩ wa Thiong'o calls the decolonization of the African mind. 69

Explicitly referring to and quoting from publications by North American conservative evangelical authors on 'biblical manhood and biblical womanhood', Banda at first sight seems to inscribe another Western gender discourse and copy it to an African context. However, as outlined above, he does not simply copy this American evangelical discourse but reworks it with some significant twists, in order to address the local issues he is concerned about, such as the high levels of HIV, gender-based violence, and disrupted families, and to make a relatively progressive contribution to greater gender equality in the Zambian context. Yet still, one could argue that the rejection of feminism because of its imposition of 'Western standards', while simultaneously engaging another Western discourse, makes Banda - and probably African Pentecostalism more generally - vulnerable to the criticism of selectivity. ${ }^{70}$ At the same time, however, such selectivity may be part and parcel of catachresis as a disruptive, and in a certain way subversive, process of appropriation. All this reflects the complexity and ambiguity of Pentecostalism as a strong religious movement and socio-cultural force in postcolonial Africa. Thus my intention here is not to contend that Banda, or African Pentecostalism in general, represents an example par excellence of catachrestic postcolonial agency as conceptualized by Spivak and Bhabha. Yet as pointed out above, Banda's sermon series does reflect a catachrestic translation of modernity in a postcolonial context, and this may be illustrative of African Pentecostalism more generally and help to understand the ambivalences in, and paradoxical character of its gender discourse.

\section{Conclusion}

Earlier I quoted Robbins, who - while surveying recent scholarship on gender and Pentecostalism - concluded that 'the question of whether or not Pentecostalism has generated among converts outside the West something that resembles Western notions of gender equality has been one of the most thoroughly debated in the literature. ${ }^{71}$ The ethnocentrism inherent in this formulation, and possibly also in much of the scholarship to which it refers, is self-evident: Western notions of gender equality are apparently the norm against which a

\footnotetext{
${ }^{69}$ Ngũgĩ wa Thiong'o, Decolonising the Mind: the Politics of Language in African Literature, London: Heinemann 1986. Musa Dube argues that this decolonizing practice is crucial for postcolonial feminism, see M.W. Dube, 'Postcoloniality, Feminist Spaces and Religion', in L.E. Donaldson and Kwok Pui-lan (eds.), Postcolonialism, Feminism, and Religious Discourse, London and New York: Routledge 2002, 100-120.

70 Cf. M. Joy, 'Revisiting Postcolonialism and Religion' in Australian Religion Studies Review 25:2 (2012), 109.

71 Robbins, Anthropology of Religion, 169.
} 
religious movement outside the West is measured. The conclusion of such an evaluation will either be that Pentecostalism does not promote gender equality and is just a new, neo-conservative, form of patriarchal religious ideology, or that Pentecostal gender discourse generally is paradoxical and ambivalent in its support of gender equality. Although I can agree with the latter conclusion, I think that it challenges us as scholars into a more critical reflection upon our analysis and evaluation of the discourse and politics on gender in African Pentecostalism. Otherwise the study of Pentecostalism in Africa is yet another illustration of Mbembe's argument that 'Africa still constitutes one of the metaphors through which the West represents the origin of its own norms, develops a self-image, and integrates this image into the set of signifiers asserting what it supposes to be its identity. ${ }^{72}$

The catachresis of gender equality in African Pentecostal circles raises some fundamental questions, both politically and academically. Politically, the questions concern the politics and strategies of gender transformation initiated by many (inter)national organizations working in Africa, whose work is informed by what Banda calls 'Western standards'. When Pentecostalism can contribute to more egalitarian gender relations without embracing the 'right' understanding of gender equality, questions arise such as what is actually meant by the phrase 'promotion of gender equality', which and whose cultural values does it entail, and what are the power politics involved? A whole field of questions concerning gender politics in postcolonial and globalizing contexts is opened up here.

Academically, Pentecostalism is a challenging subject for scholars in the interdisciplinary study of religion and gender, whose work is often informed by feminist or gender-critical lenses. Gender-critical scholars have been quick to criticize Pentecostalism for reinforcing patriarchal values, but have hardly attended to the challenges and possible critique that Pentecostalism itself may present to their scholarship and its underlying political agenda. The question raised by Mahmood in view of women's participation in the Mosque movement in Egypt can also be applied to Pentecostalism (which is also largely a women's movement): 'What do we mean when we as feminists say that gender equality is the central principle of our analysis and politics? ${ }^{\prime 73}$ The meaning of gender equality has often been taken for granted, as has the meaning of a gender-critical approach to religious discourse. However, in view of Pentecostalism we become aware of the complexity of religious gender discourse and we are faced with alternative conceptualizations of gender equality. How to grasp that complexity? How to evaluate these alternative concepts of gender equality and the criticism they pose to the implicit or explicit norms of gender equality that underlie our own scholarship? As Elizabeth Brusco put it in her overview of gender in Pentecostalism, 'a recognition that there are other paths toward change, other approaches to a good life, and other value systems seems like a critical starting point in understanding the growth of Pentecostalism', particularly in understanding Pentecostal gender politics from a postcolonial perspective. ${ }^{74}$

\footnotetext{
72 Mbembe, On the Postcolony, 2.

73 Mahmood, Politics of Piety, 38.

74 E. Brusco, 'Gender and Power' in Anderson et al. (eds.), Studying Global Pentecostalism, 88.
} 


\section{Acknowledgement}

I am grateful to the participants of the workshop Catachreses? 'Religion', 'Gender' and 'Postcoloniality' at SOAS, University of London (17-19 December 2012), the anonymous reviewers, my co-editor of this special issue, Dr. Sian Hawthorne, and Prof. Anne-Marie Korte, whose questions and comments on earlier versions of this article have greatly helped me to develop and fine-tune the argument. 